\title{
Study On Rice Production Enhancement In Bandung District
}

\section{Nuraeni Arumsari, Muhammad Tasrif}

Institut Teknologi Bandung

arumrie@gmail.com

\begin{tabular}{|c|c|}
\hline Article Info & Abstract \\
\hline $\begin{array}{l}\text { Clause history: } \\
\text { Received January 21,2019 } \\
\text { Revised August 01,2019 } \\
\text { Accepted August } 31,2019 \\
\text { Available online September } \\
01,2019\end{array}$ & $\begin{array}{l}\text { Agricultural enterprises have a very high dependence } \\
\text { on land. If the availability of agricultural land is } \\
\text { threatened, the agricultural products are threatened. } \\
\text { The development of a region also requires land, but } \\
\text { sometimes due to land constraints, there is a lot of } \\
\text { conversion of agricultural land, including rice fields }\end{array}$ \\
\hline 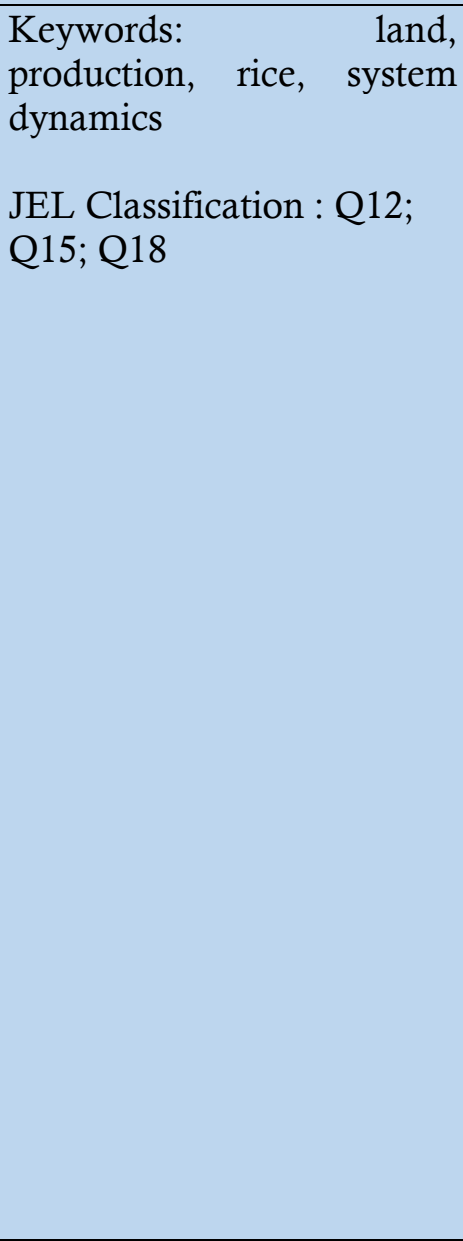 & $\begin{array}{l}\text { Regency is one of the areas that cannot be separated } \\
\text { from the problem of development and conversion of } \\
\text { agricultural land, meanwhile Bandung Regency is one } \\
\text { of the contributors to the availability of food crops, one } \\
\text { of them is rice. The government's target to be self- } \\
\text { sufficient in food and make Indonesia as the world's } \\
\text { food granary in } 100 \text { years of Indonesia's independence } \\
\text { makes Bandung Regency must join efforts to increase } \\
\text { rice production in the midst of widespread land use. } \\
\text { This research was conducted to model the dynamics of } \\
\text { rice production in Bandung regency. The approach } \\
\text { used is system dynamics methodology that can } \\
\text { contribute in understanding a problem built through } \\
\text { dynamic hypothesis. Through the system dynamics } \\
\text { method, a model developed illustrating the increase in } \\
\text { rice production by identifying the various related } \\
\text { elements and patterns of interrelationships between } \\
\text { them. With the help of the model, several policy } \\
\text { scenarios can be designed to increase rice production. } \\
\text { The results showed that rice production if not } \\
\text { intervened by policy, the rate of growth will decrease, } \\
\text { especially if the over of fixed land functions still occur. } \\
\text { The policy of using new varieties, namely INPARI } 42 \\
\text { with a delay time of } 3 \text { years implementation, coupled } \\
\text { with pest prevention policies, availibility and } \\
\text { affordability fertilizers, and irrigation improvement } \\
\text { can encourage the growth rate of rice production in } \\
\text { Bandung Regency. }\end{array}$ \\
\hline
\end{tabular}

\section{INTRODUCUTION}

The problem of food security in Indonesia is still a complicated issue to be solved. As an agrarian country, Indonesia is still unable to overcome the imbalance between population growth and food availability. This will continue in the future, given that the source of problems such as the conversion of agricultural land to non-agricultural land, the decline in the number of agricultural households, the knowledge of farming communities, to irrigation problems and especially population growth cannot be solved. 
Bandung Regency as one of the regencies in West Java Province is one of the districts contributing to the availability of rice, and is also inseparable from the problem of changing the function of paddy fields.

Control over the function of paddy fields is an important effort that must be taken in order to support the availability of rice. Controlling rice field conversion which is carried out effectively and efficiently is not able to significantly increase rice production, but it is needed to reduce the problem of rice production. Because the problems caused by the conversion of paddy fields are permanent, meaning that the problems caused will still be felt in the long run even though the land use change has no longer occurred. In addition to land use change, there are some problems in rice production that are temporary in nature, in the sense that the problem only arises when the event occurs, including pest attacks, drought, floods, irrigation network damage, and falling rice prices.

\section{METHOD}

Rice production in a year (tons / year) is determined by the area of land planted with rice (ha), yield per hectare of varieties (seeds) of rice planted (tons / ha), multiplier factor of soil fertility [without dimension or ()], factors multiplier pest disorder [without dimension or ()], and intensity of rice planting in a year (/ year). The rice production equation can be written as follows:

$\mathrm{P}=\mathrm{L}$ * $\mathrm{Y}$ * $\mathrm{FS}$ * $\mathrm{FH}$ * $\mathrm{I}$

where $\mathrm{P}=$ rice production (tons / year); $\mathrm{L}=$ area of land planted with rice (ha); $\mathrm{Y}=$ yield per hectare of rice varieties (ton $/ \mathrm{ha}$ ); FS = multiplier factor for soil fertility (); $\mathrm{FH}=$ factor pest multiplier (); $\mathrm{I}=$ intensity of rice cultivation (/ year)

System dynamics or often called system dynamics is a method of "seeing" a system, which is meant by "seeing" here means to describe, understand, analyze, with the intention to redesign policies that affect a system. The system is defined as a set of elements that interact with each other. Saswinadi Sasmojo (2004) defines the system as a phenomenon whose structure has been defined. Departing from the system, then the system thinking approach is created which is a method of analysis that studies how one thing affects other things as a whole (Sterman, 2000). The system thinking approach is the foundation of the system dynamics approach. The principles of the systems thinking approach are as follows:

1. Emphasis on cause-effect relationships.

2. Aim to understand the causes of the results that occur.

3. Causal relationships occur with the assumption of "ceteris paribus".

4. The element of time must always be taken into account. From time to time, circular causal relationships occur, creating a feedback effect.

5. Endogenous perspective, the point is that the internal structure causes the dynamic behavior of the output that occurs.

The dynamics system methodology has been and is developing since it was first introduced by Forrester in the decade fifty years ago and based at MIT in the United States. The system dynamics methodology emphasizes causal relationships, changes over time, and input expressed in a model. There are two kinds of causal relationships, namely: positive causal relationships and negative

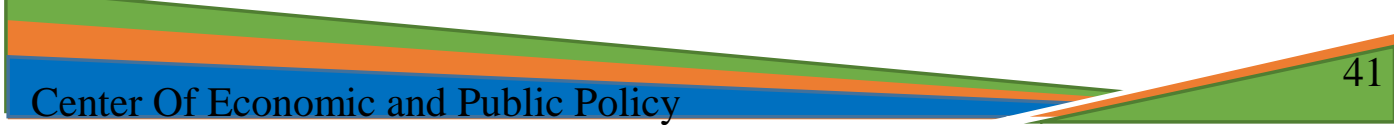


causal relationships. Negative feedback describes a process for achieving goals (goal seeking). This feedback balances any disturbance that arises and then brings the system into a stable state. Positive feedback occurs if changes in system components will cause changes in other components that will strengthen the process (reinforcing) Basically the dynamics system model is a system of differential equations, but uses numerical integration over time that can be solved analytically. These characteristics allow the development of complex models but are relatively easy to understand. This is the main goal of the system dynamics approach, which is to facilitate understanding of an issue and its dynamics.

This study uses the system dynamics methodology because this methodology is able to recognize the elements in the system and the patterns of interrelationships among the elements in the system and be able to show the relationship that affects the overall system behavior in a model. The use of this methodology is considered appropriate because it can describe the linkages of elements explicitly in the problem of rice production in Bandung District and also illustrates feedback on the problem.

\section{RESULT AND DISCUSSION}

\section{Model Limits}

System dynamics modeling is an attempt to represent real world phenomena into a computer simulation model whose purpose is to describe real world phenomena, predict the short-term and long-term outcomes of a problem and also policy solutions, and more importantly, to provide an understanding more comprehensive about a phenomenon or problem that occurs. It is hoped that the best policy can be based on this understanding.

Many experts argue that the quantification of qualitative variables used in modeling dynamics systems often creates uncertainty, therefore simulation results from modeling dynamics systems are often considered to be misdirected, or at least very fragile (Coyle, 2000). It is the limitations of knowledge and perceptions that humans have that cause this to happen. Therefore, in modeling dynamics systems, model constraints need to be made to be able to represent phenomena and also improve understanding of phenomena or problems. These restrictions will categorize which variables are included endogenous, exogenous, and also variables that are outside the model boundary. Endogenous variables are variables whose value is determined by the interaction of the model included in the causal circle, exogenous variables are variables that affect the state and dynamics of the model, but are not influenced by the model. While variables outside the boundary are variables that cannot be influenced or affect the model.

As mentioned above, rice production is affected by the area of paddy fields, yield of rice varieties planted, soil fertility, pest disturbance and intensity of rice cultivation. The area of paddy fields is affected by land conversion to non-agricultural land as a result of increasing population in Bandung Regency. Based on data and conditions in the field, the rice varieties used do not always reach the maximum value (optimal) due to the influence of soil fertility and pest disturbance. The intensity of planting even though it cannot be maximally

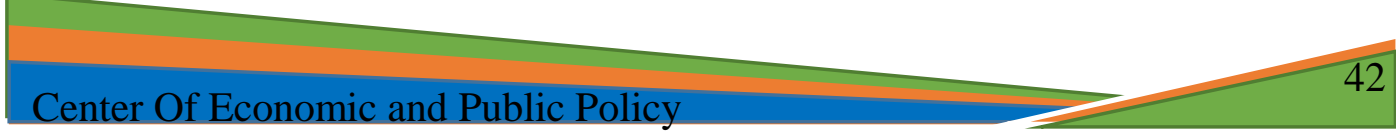


carried out because it is influenced by water availability. Therefore, in this study the variables related to the rice production model in this study are as follows:

Table 1. Limitation of Rice Production Models

\begin{tabular}{ccc} 
Endogenous Variables & Exogenous Variables & $\begin{array}{c}\text { Beyond the Model } \\
\text { Boundary }\end{array}$ \\
\hline $\begin{array}{c}\text { Rice Production } \\
\text { not land }\end{array}$ & Paddy fields & Weather \\
& Population & human Resources \\
& Planting Intensity & subsidy \\
yield &
\end{tabular}

Source : analysis data

\section{Structure of Rice Production Model}

The behavior of a model depends on the components that exist and the interrelationships between these components and the parameters inherent in each component. Building a model structure means making a causal loop diagram that can reflect the real system. The structure of the model is then developed and studied the behavior of each observed variable. Then the behavior of each variable is assessed and formulated so that it can be simulated to find out the behavior of the variables reviewed in relation to changes in time. The following is a causal loop diagram of rice production in Bandung Regency:

\section{Figure 1. Rice Production Causal Loop Diagram in Bandung Regency}

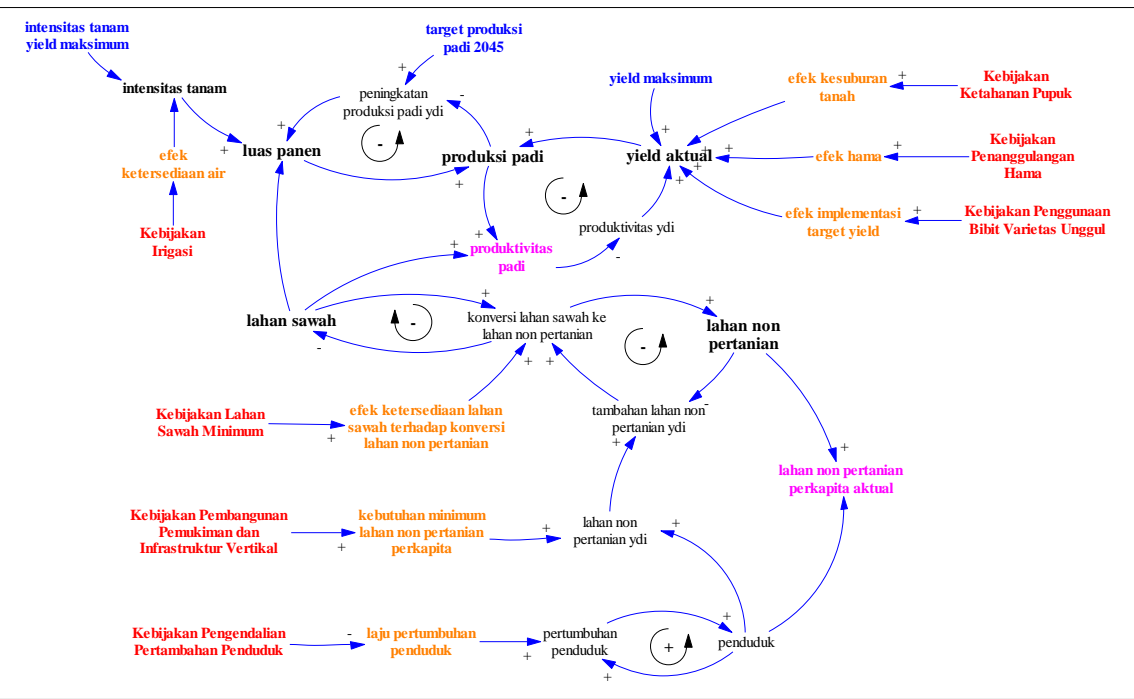

Source : analysis data

The structure of the global model in this study consists of causal loop diagrams of several sub models interacting to form the overall system. Each sub-model, in addition to interacting with other sub-models also has an internal interaction between the structural components owned by the sub-model concerned. The global model of rice production in Bandung Regency is formed by 4 sub-models, namely the sub-land model, the desired non-agricultural land 
sub-model, the rice production sub-model, and the target yield implementation sub-model.

\section{Land Sub Model}

The land sub-model illustrates the dynamics of the function of changing paddy fields to non-agricultural land. Transfer of paddy land is influenced by the need for non-agricultural land, such as for housing, industry, infrastructure, and other commercial buildings. The amount of land conversion is limited by the large area of paddy fields that must be maintained, because otherwise the paddy fields will be exhausted, so that Bandung Regency can no longer produce rice. Following is the flow diagram of the sub-land model:

Figure 2. Flow Chart of Land Model Sub

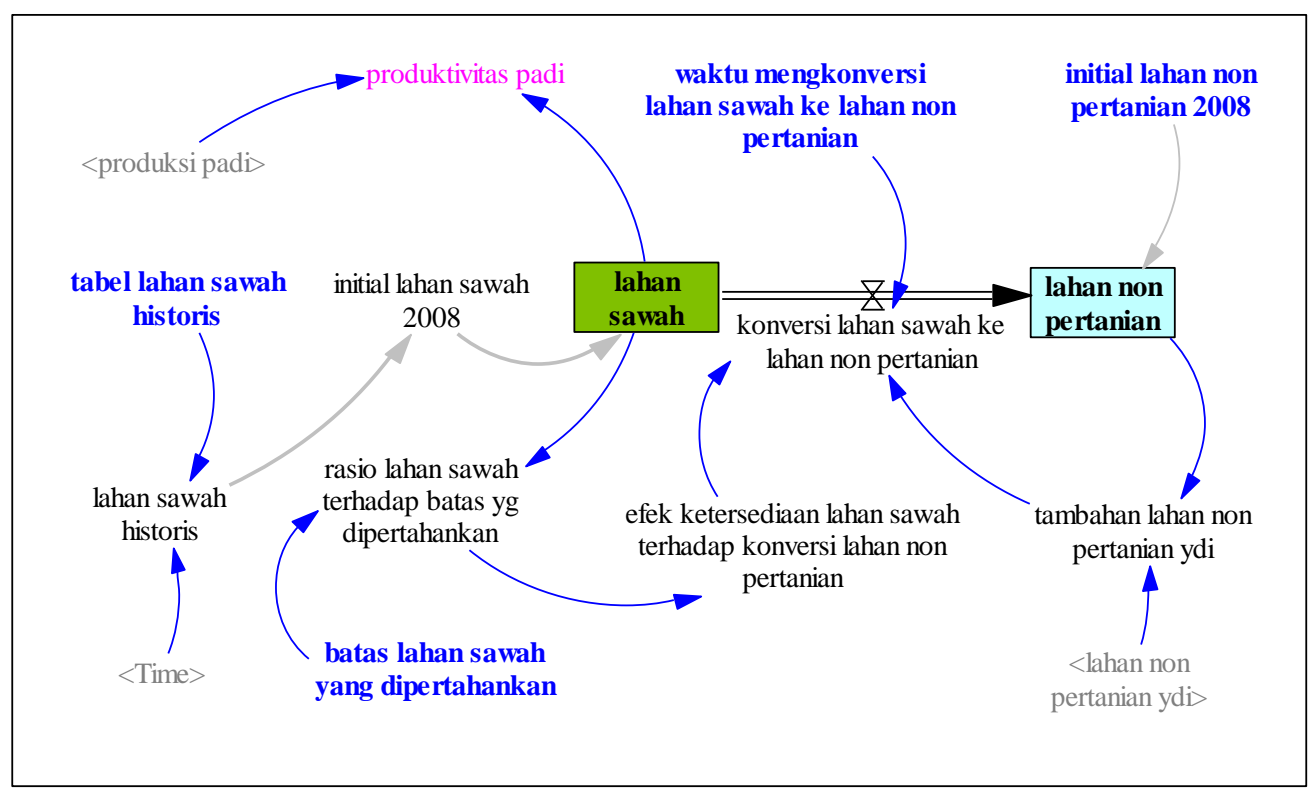

Source : analysis data

\section{Desired Non-Agricultural Land Model}

Desired non-agricultural land models describe the dynamics of nonagricultural land requirements due to population growth. The higher the number of population, the greater the need for non-agricultural land. But the availability of non-agricultural land is also not unlimited, therefore the need for non-agricultural land is also influenced by the minimum non-agricultural land requirements per capita. Following is the flow diagram of the desired nonagricultural land sub-model: 
Figure 3. Flow Chart of Desired Non-Agricultural Land Model

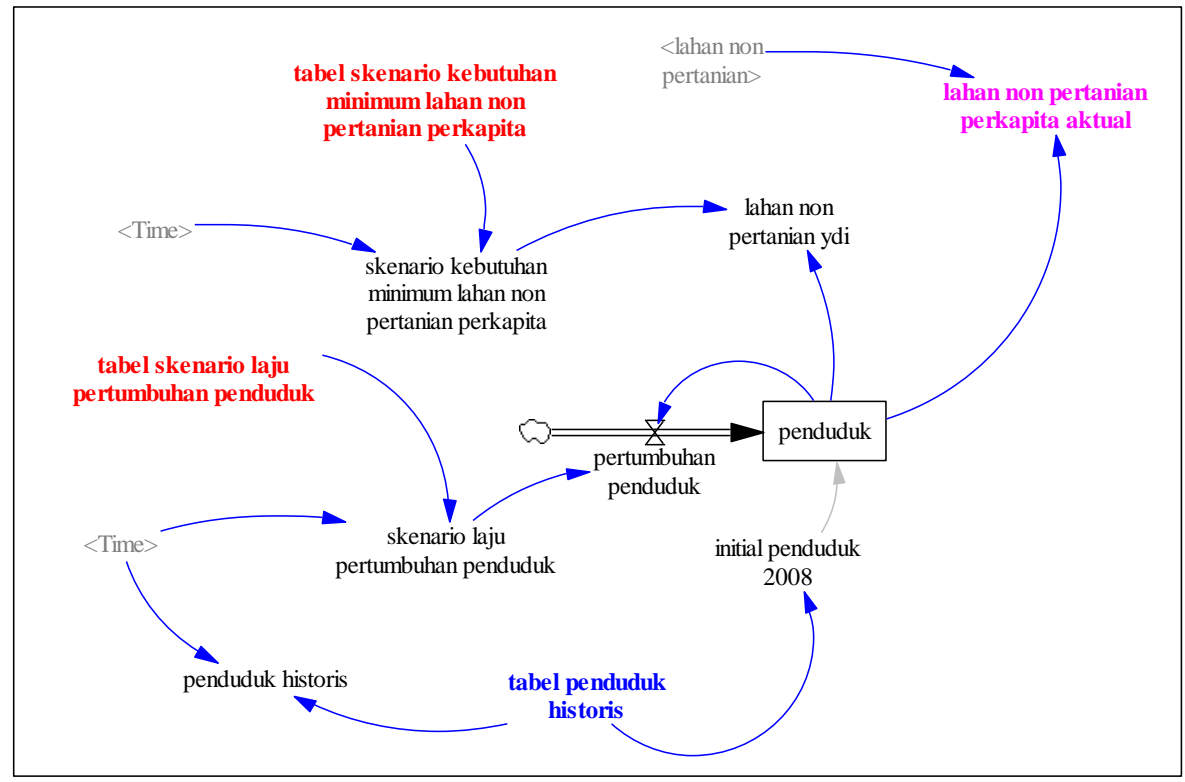

Source : analysis data

\section{Rice Production Sub Model}

The rice production sub-model illustrates the dynamics of rice production which is influenced by harvest area and yield factors. Harvested area is influenced by the size of rice fields and cropping intensity. The amount of cropping intensity depends on the variety of rice seeds used, as well as the amount of yield. Each rice seed variety has its own cropping intensity and potential yield. The optimal intensity of planting depends on the availability of water in the paddy field. While the optimal yield obtained depends on whether soil fertility and pest problems. Following is the flow diagram of the rice production sub-model:

Figure 4. Flow Diagram of Rice Production Sub-Model

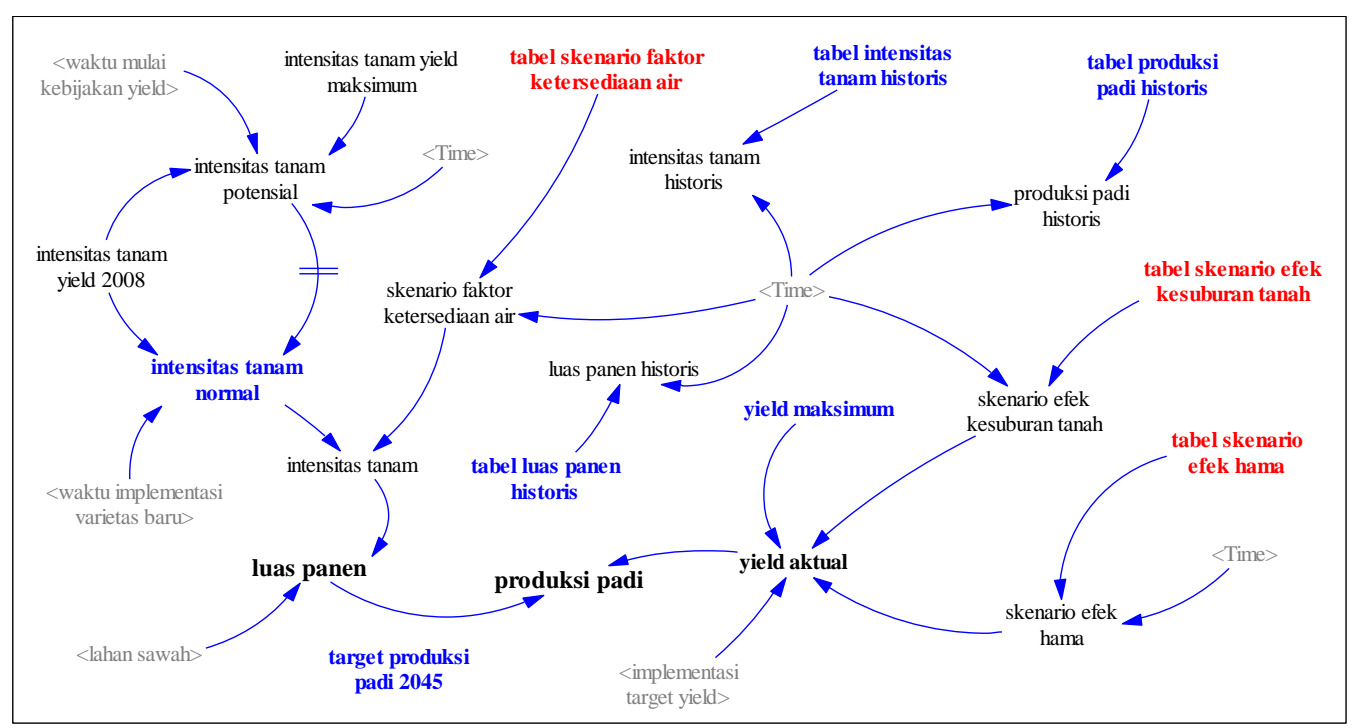

Source : analysis data 


\section{Implementation of Target Yield Sub Models}

The implementation of the yield target is influenced by the potential yield of seed varieties used in 2008, where the average farmer uses ciherang seed varieties, the maximum yield of current rice seed varieties, the share of paddy fields with 2008 yields, and the share of paddy fields with maximum yields also affects the share of paddy fields with 2008 yields and paddy fields with maximum yields. While the share of paddy land with maximum yield is influenced by the share of paddy land with potential maximum yield, share of paddy land with maximum yield of 2008, and the time of implementation of new varieties. the share of paddy land with maximum yield is potentially influenced by the share of paddy land with maximum yield of 2008, the time of yield yield policy, and the target of the share of paddy land with maximum yield. Following is the flow diagram of the target yield implementation submodel:

\section{Figure 5. Flow Diagram of Target Yield Implementation Sub Models}

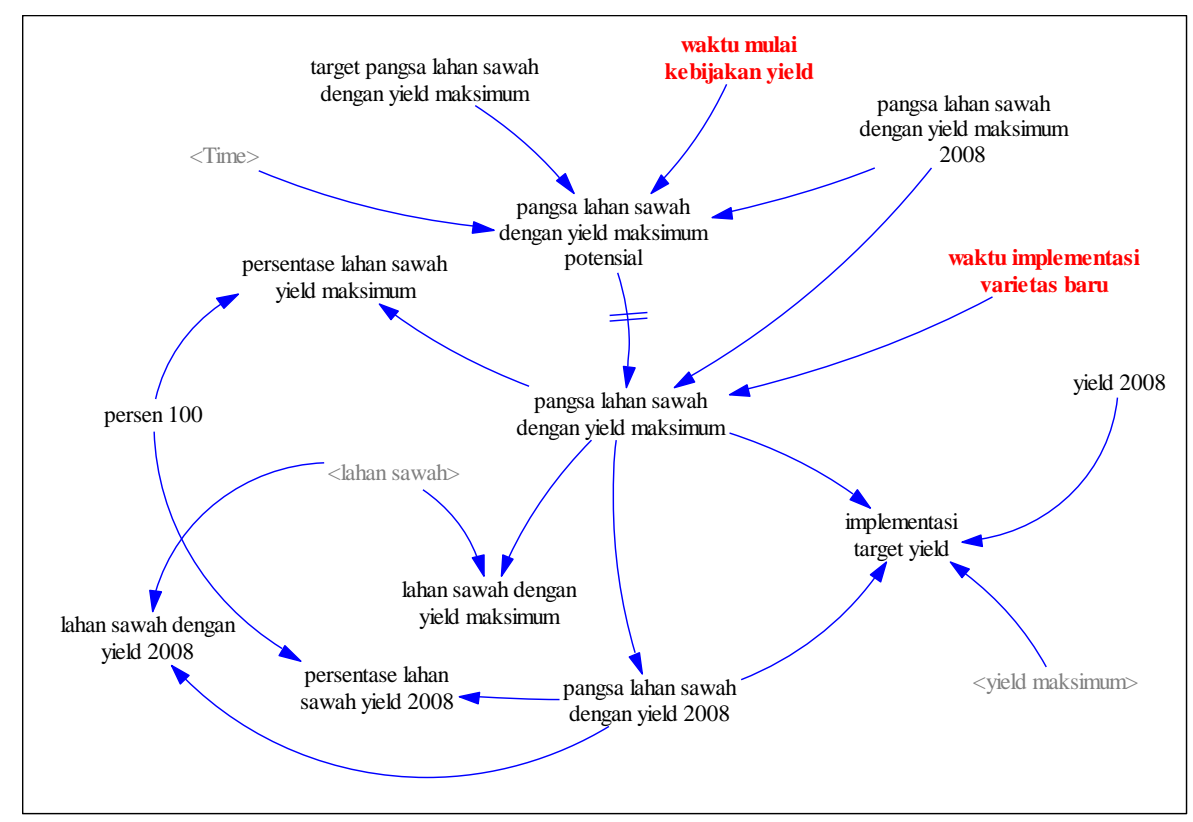

Source : analysis data

\section{Model Behavior in Basic Scenarios}

Basically, the simulation is done to find out how the model will tend to behave in the future. To find out the future behavior of the model, a simulation is carried out until 2045, which is 100 years of Indonesian Independence. The start time of the simulation is 2008 and ends in 2045. In the basic scenario there is no change in the values of variables and parameters or no intervention is carried out. Simulation results are shown in the following figure. 


\section{Figure 6. Basic Scenario Simulation Results}

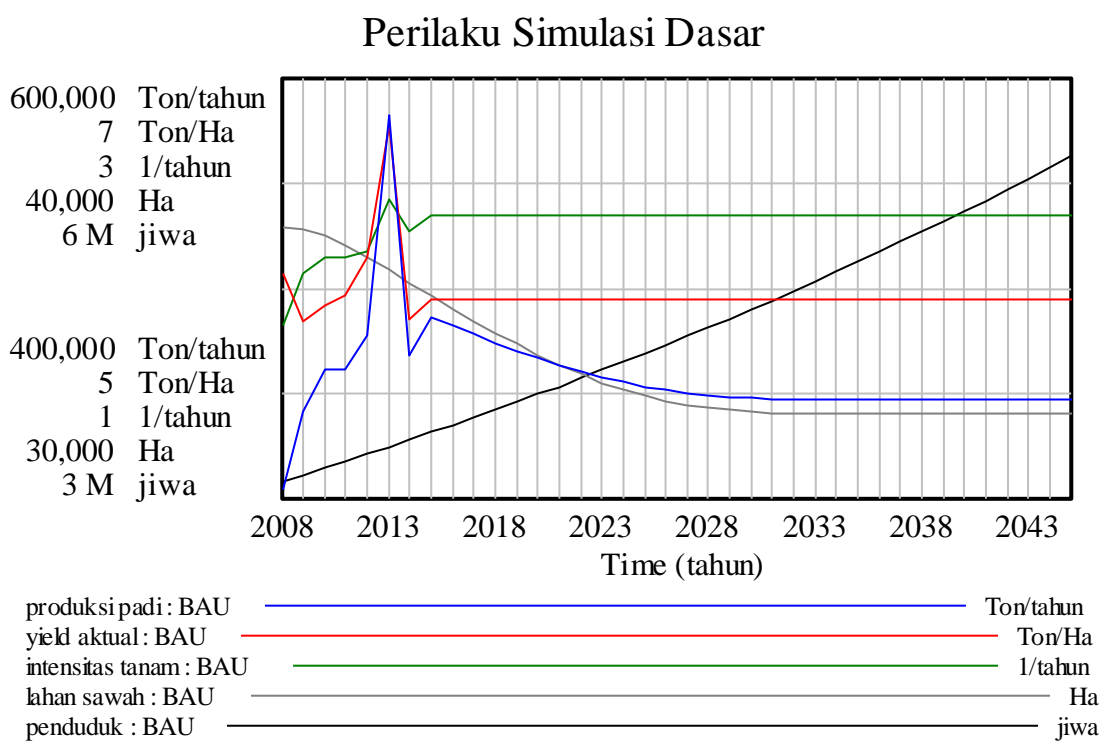

Source : analysis data

From the simulation results it can be seen that the behavior of the model has not improved from historical simulations, this shows that when the structure of the model is not carried out any intervention on variables that are considered sensitive then the behavior of the model will not change. The basic scenario model without any improvement efforts, especially on the availability of water, pest control, increasing soil fertility, and research on new rice seed varieties that are the authority and responsibility of the government, rice production will not achieve maximum results.

The results of the basic scenario simulation in the model are not expected conditions for future rice production in the real world, especially if you want the government's target as a world food barn to be achieved in 2045 . For this reason it is necessary to intervene the variables in the model that are considered sensitive that can improve behavior model. By improving the behavior of the model it is hoped that it can become input in developing alternative policies to improve the real world phenomenon in the future.

\section{Model Behavior in Policy Scenarios}

To improve the behavior of the model an analysis of the behavior of certain variables is carried out. In accordance with the objectives of this study, intervention scenarios were carried out mainly on sensitive variables that would change the behavior of the model. The first policy scenario is to intervene in each variable except the time variable starting the implementation of new varieties. Obtained simulation results as follows: 
Figure 7. Results of the Policy Simulation to be Implemented in 2018

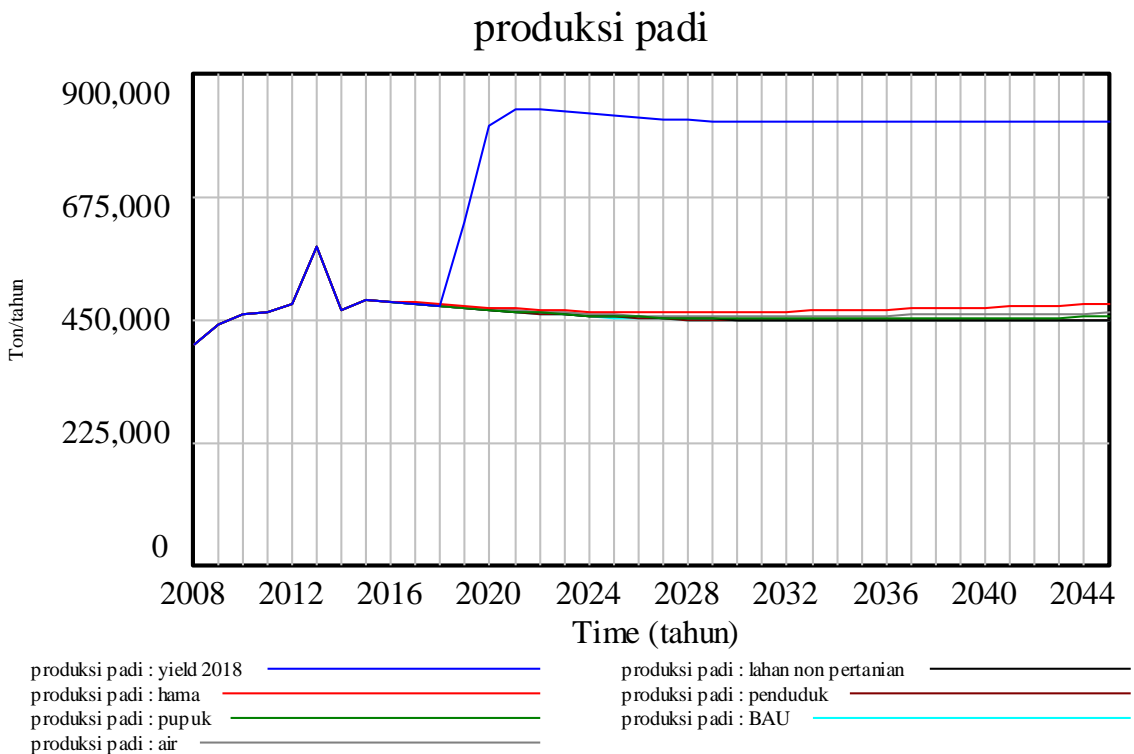

Source : analysis data

It appears that the policy for the use of new seed varieties is the most sensitive variable with the most significant rice production. If the variable usage of new seed varieties is not implemented, the following graph is obtained:

Figure 8. Results of Policy Simulation Starting to be Implemented in 2018 Without Yield Policy

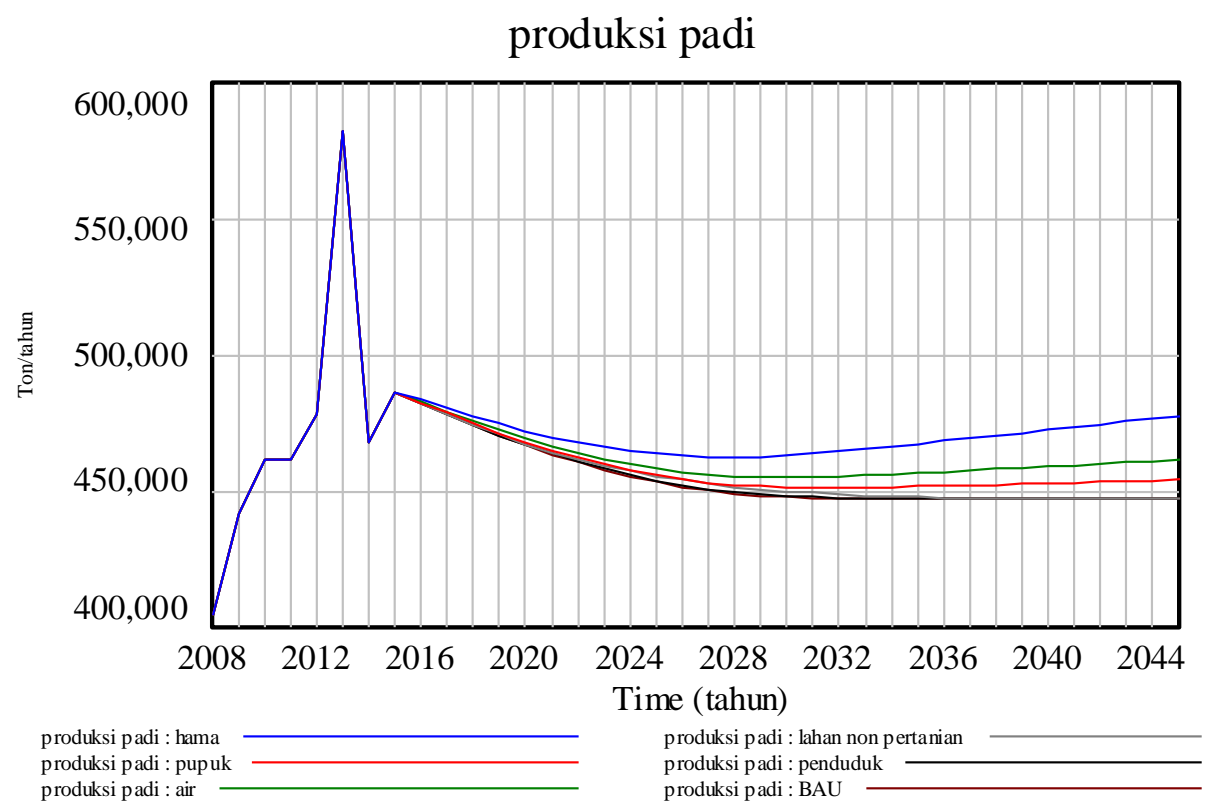

Source : analysis data

It appears that sufficiently sensitive variables produce significant rice production after the variable use of new seed varieties are effective pest control, adequate water supply, and appropriate fertilizer application. 
As stated above, the use of new seed varieties is the most sensitive variable with the most significant results of rice production simulation, but the policy is only implemented after 5 years. The following is a chart comparison with the time to implement the new varieties of seeds 3 years and 5 years.

Figure 9. Results of Yield Policy Simulation Starting to be Implemented in 2018, Delay of 5 Years vs. Delay of 3 Years

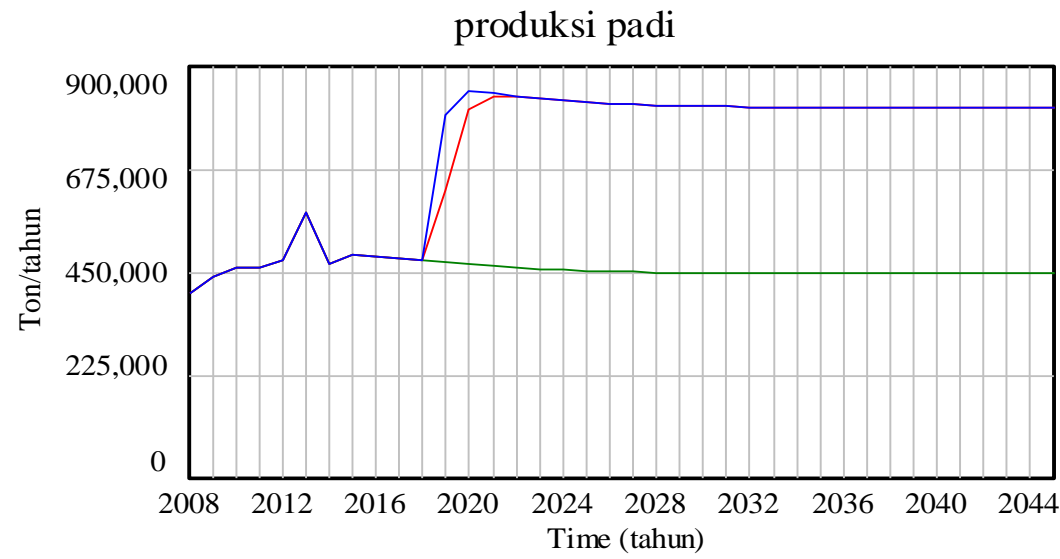

produksi padi : yield 2018 yield butuh 3 tahun produksi padi : yield 2018 produksi padi : BAU

Source : analysis data

It can be seen that the policy for the use of new seed varieties with a 3year delay results in a better simulation of rice production than the use of new seed varieties with a 5-year delay. Based on some of the simulation results above, if several sensitive policies are implemented simultaneously the following graph is obtained.

Figure 10. Several Policies Implemented Simultaneously Starting in 2018

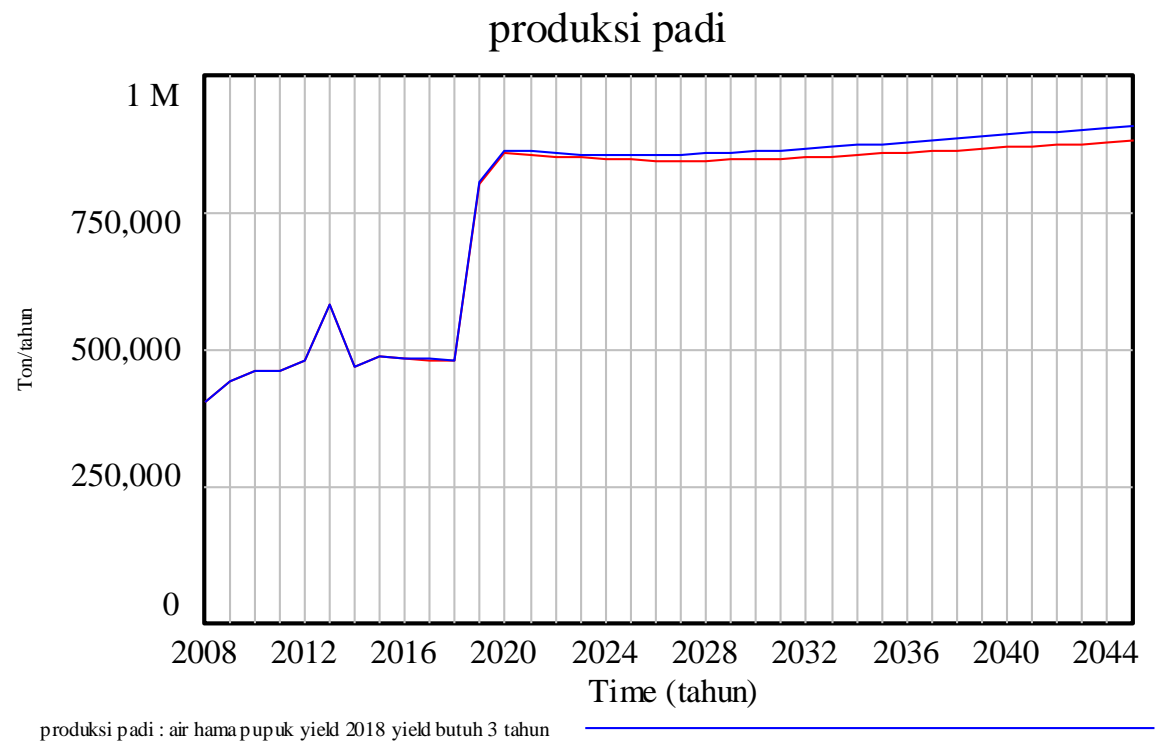
produksi padi : air hama pupuk yield 2018 yield butuh 3 tahu
produksi padi : hama pupuk yield 2018 yield butuh 3 tahun

Source : analysis data 
From the graph, it can be seen that the policy to use new varieties of seeds with implementation time as soon as possible, in this simulation that is 3 years, if coupled with effective pest management policies, the use of appropriate fertilizers and sufficient water supply will result in higher rice production than if the policy which is only accompanied by effective pest control and the use of appropriate fertilizers.

The simulation results by changing the variable population growth rate or the minimum non-agricultural per capita land need variable does not show much difference compared to the scenario without policy, this shows that the minimum non-farm per capita land requirements and the population growth rate do not have too much impact on the model results. This is because the paddy fields needed to grow rice have reached the lower threshold. It is impossible to do the addition of paddy fields by changing the function of nonagricultural land to paddy fields. In addition, the availability of land as well as mutual attraction with the needs of non-agricultural land, such as housing, industrial buildings, commercial buildings, infrastructure and others. In this scenario, the minimum per capita non-agricultural land demand will fall, which means that in the coming years development will be implemented with upward development, no longer on the sidelines. For example, increasing the construction of flats, construction of industrial and commercial buildings vertically, overpass construction, and so forth. Likewise, the rate of population growth is made down, meaning that in the future the government is more aggressively conducting small family programs, such as Family Planning (KB), and so forth. These two things indeed cannot directly increase rice production, but with the decrease of these two variables can at least maintain the availability of land to produce rice.

The development of agriculture, especially rice food in Bandung regency, has not yet shown encouraging results. Basic simulation results show that the rate of growth of rice production has not yet yielded satisfactory results. Under these conditions, efforts to achieve an increase in the rate of growth of rice production by 5 percent per year may not be achieved until 100 years of Indonesian independence, namely in 2045. Many factors affect this, including the conversion of paddy fields to non-agriculture which not only seizes land rice fields are available, but result in a lack of water availability for rice fields. If the weather is good, in the sense of being in accordance with the conditions of agriculture, of course the availability of water is not a problem for farmers to produce rice optimally. It is different if the weather enters the dry season, where rice fields can experience drought, this is certainly an obstacle for farmers. In this case the role of government is needed. The government can budget irrigation improvement if indeed the irrigation channel is experiencing problems either damaged due to age or because it is obstructed by the construction that was established between the water source and the rice fields. There are many ways that the government can do with various policies to ease the burden on farmers. Provision of water pumps for farmers when they are experiencing drought, one of them. Currently in Bandung Regency the supply of pumps is already running, but the number of pumps available with rice fields that require water assistance is still not comparable. Not to mention the cost of

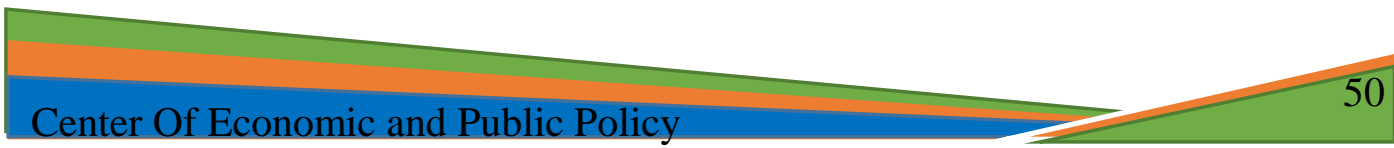


transporting pumping equipment and fuel costs that must be borne by farmers is a constraint for farmers.

New improved seed varieties can basically be a solution in increasing rice production. Substitution of new varieties can reduce pest failure problems because pests do not recognize the new varieties. But in reality the application is not easy. The habit, culture, and taste of rice produced from the rice varieties currently used is one of the obstacles of the government to implement new varieties to farmers. Therefore, integrated counseling is needed in order to introduce new varieties to farmers. At present there are many agricultural extension agents assigned by the Agriculture Office in each region as a bridge to connect farmers with the government in dealing with all kinds of problems related to rice, including the problem of new varieties. But this has not been done optimally due to several things both from the farmers themselves and agricultural extension officers assigned by the local Agriculture Service. Drought and pest problems that often occur that result in decreased or not optimal rice production can basically be dealt with immediately so that it does not harm the farmers if the communication between farmers and agricultural extension workers can go well.

In addition, human resources must also be considered by the government to increase rice production. The reluctance of people, especially the productive age to become farmers, is an obstacle to increasing rice production. Income which is considered insufficient is the main reason for Indonesia's agricultural sector experiencing a shortage of human resources. The high value of production to produce rice is also an obstacle in the agricultural sector. Some policies related to subsidies have been widely implemented by the government to increase rice production, but in reality there are still many irregularities that occur, this must also be a concern of the government in order to be anticipated.

Provision of agricultural tools that can facilitate the task of farmers in working on the fields is not yet done by the government at this time. However, these programs are often not well targeted or not in accordance with the conditions of the fields cultivated by the farmers who received the assistance. Therefore, two-way communication between farmers and policy makers is one solution that can overcome various agricultural problems, especially the problem of rice. If communication goes well, of course farmers can get assistance programs in accordance with what is needed so that rice production can increase.

\section{CONCLUSION}

Based on the results of simulations and analyzes that have been done there are several things that can be concluded regarding the increase in rice production in Bandung Regency as follows:

The most significant policy is the yield increase policy, namely by replacing the seed varieties used today, namely Ciherang, potential yields of 7 tons / ha, with suggested high yielding varieties namely INPARI 42, potential

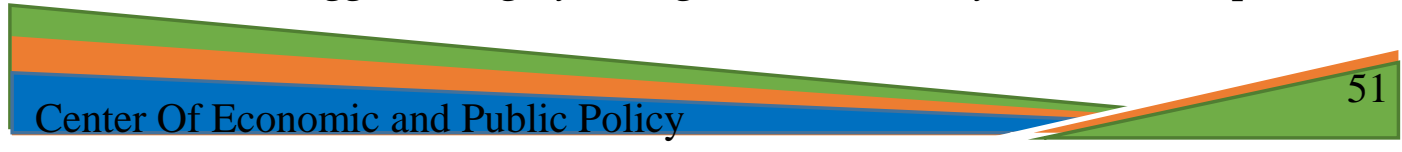


yields of 10.58 tons / ha, while other policies are less significant in increasing rice production. The policy in point 1 is recommended to be implemented with a time delay of 3 years. This can be done through efforts to ensure the availability of superior seeds needed by farmers, according to the amount needed at an affordable price through the independent seed program. The policy on the use of new varieties, namely INPARI 42 with a implementation delay of 3 years, coupled with policies on pest control, fertilizer resistance, and irrigation improvement can further increase rice production in the long run.

\section{REFERENCE}

Tasrif, M. (2017). Model System Dynamics Produksi Beras (Dalam Konteks Surplus Beras). Program Studi Pembangunan ITB, Bandung

Sasmojo, S. (2004). Sains, Teknologi, Masyarakat Dan Pembangunan. Program Pascasarjana Studi Pembangunan ITB, Bandung

Sterman, John D. (2000). Bussiness Dynamics, System Thinking And Modelling For A Complex World. The Mcgraw-Hill Companies Inc., Boston

Saeed, K. (1992). Slicing A Complex Problem For Systems Dynamics Modeling. System Dynamics Review 8

Sterman, John (1994). Learning In And About Complex Systems. System Dynamics Review

Saeed, K. (1995). The Organization Of Learning In System Dynamics Practice. Unpublished Paper. Bangkok. Asian Institute Of Technology

Tasrif, M. (2001). Kumpulan Bahan Kuliah Pemodelan. Program Studi Pembangunan ITB, Bandung

Creswell, J.W. (1998). Qualitative Inquiry And Research Design Choosing Among Five Traditions. USA: Sage Publications

Bogdan, R, Dan Taylor, S. (1993). Kualitatif Dasar - Dasar Penelitian. (A. Khozin Affandi, Penerjemah). Surabaya : Usaha Nasional

Maxwell, Joseph A. (1996). Qualitative Research Design: An Interactive Approach. USA: Sage Publications

Wahab, Rochmat. (2003). Jurnal Bimbingan Dan Konseling : Bimbingan Sosial - Pribadi Berbasis Model Pengembangan. Bandung : ABKIN.

Forrester, J. W. (1980). Information Sources For Modeling The National Economy. Journal Of The American Statistical Association. 75

Sihaloho, Martua. (2004). Konversi Lahan Pertanian Dan Perubahan Struktur Agraria. [Tesis] Sekolah Pascasarjana. Bogor: Institut Pertanian Bogor.

Hidayat, S. Imam. (2008). Analisis Konservasi Lahan Sawah Di Propinsi Jawa Timur. Jurnal-SEP. Vol 2 No 3. Diakses Oktober 2014.

Kustiwan, Iwan. (1997). Permasalahan Konversi Lahan Pertanian Dan Implikasinya Terhadap Penata Ruangan Wilayah: Studi Kasus Wilayah Pantai Utara Jawa. Jurnal PWK. Vol 8 No 1. 
Purwanto, Et. A1. (2008). Dampak Alih Fungsi Lahan Pertanian Ke Sektor Non Pertanian Terhadap Ketersediaan Beras Di Kabuapaten Klaten Jawa Tengah. Jurnal (Caraka Vol XXV No 1. Diakses Oktober 2014.

Suparyono Dan Agus Setyono. (1993). Padi. Penebar Swadaya. Jakarta

Moehar, Daniel. (2002). Pengantar Ekonomi Pertanian. Jakarta : PT. Bumi Aksara.

Hanafi, Rita. (2010). Pengantar Ekonomi Pertanian. Andi Offset. Yogyakarta

Kholic, Abdul. (2004). Upaya Peningkatan Pendapatan Rumah Tangga Tani Melalui Penggunaan Padi Varietas Unggul Baru, BPTP. Jawa Tengah.

Purwaningsih, Yunanstiti. (2008). Ketahanan Pangan: Situasi, Permasalahan, Kebijakan, Dan Pemberdayaan Masyarakat. Jurnal Ekonomi Pembangunan Vol. 9, No. 1, Juni 2008, Hal. 1 - 27

Tambunan, Tulus. (2017). Ketahanan Pangan Di Indonesia : Inti Permasalahan Dan Alternatif Solusinya. Pusat Studi Industri Dan UKM, Universitas Trisakti. Kadin Indonesia. 2017

Sunari, Anwar. (2015). Kebijakan Ketahanan Pangan Di Indonesia. Direktorat Pangan Dan Pertanian. Kementerian Perencanaan Pembangunan Nasional/Bappenas. Disampaikan Dalam Acara Seminar "Kerentanan, Ketahanan Pangan Dan Politik Perlindungan Sosial Di Indonesia. Yogyakarta 10 Desember 2015.

Irawan B, Winarso B, Sodikin I, Gatoet SH. (2004). Analisis Faktor Penyebab Perlambatan Produksi Komoditas Pangan Utama. Pusat Penelitian Dan Pengembangan Sosial Ekonomi Pertanian.

BPS Kabupaten Bandung. (2008, 2009, 2010, 2011, 2012, 2013, 2014, 2015, 2016). Kabupaten Bandung Dalam Angka. BPS Kabupaten Bandung

Pikiran Rakyat. (2015). Lokasi Pemerintahan Dulunya Areal Sawah Kelas Satu dari http://www.pikiran-rakyat.com/bandungraya/2015/03/05/318568/lokasi-pemerintahan-dulunya-areal-sawahkelas-satu diakses pada tanggal 29 September 2017

BKPD Provinsi Jawa Barat. (2014). RENSTRA 2013-2018 dari http://bkpd.jabarprov.go.id/wp-content/

uploads/2014/06/RENSTRA-2013-2018-FINAL.pdf diakses pada tanggal 18 Agustus 2017

Humas Pemerintah Kabupaten Bandung (2016). Produksi Pangan di Bandung Fluktuatif dari http://www.jabarprov.go.id/index.php/news/ 15760/2016/01/22/Produksi-Pangan-Di-KabBandung -Fluktuatif diakses pada tanggal 18 Agustus 2017

Adi Ginanjar Maulana \& Hedi Ardhia. (2016). Alih Fungsi Lahan Pertanian, Pemkab Bandung Perketat Pengawasan dari http://industri.bisnis.com/read/ 20160317/99/529132/alih-fungsi- 
lahan-pertanian-pemkab-bandung-perketat-pengawasan diakses pada tanggal 18 Agustus 2017

Dedy. (2016). Lahan Sawah di Kabupaten Bandung Terus Tergerus dari http://www.wibawanews.net/ view.php?id=20160527173123 diakses pada tanggal 18 Agustus 2017 